\title{
Plasmin-tumour necrosis factor interaction in the ovulatory process
}

\author{
W. J. Murdoch \\ Department of Animal Science, University of Wyoming, Laramie, WY 82071, USA
}

\begin{abstract}
Collagen breakdown and apoptotic cell death within the apex of the preovulatory ovine follicle are hallmarks of impending ovarian rupture. An integrative mechanism is proposed whereby gonadotrophic stimulation of urokinase-type plasminogen activator secretion by the follicular-contiguous ovarian surface epithelium elicits a localized increase in tissue plasmin, which activates collagenolysis and tumour necrosis factor $\alpha$ induced cell death within the formative ovulatory stigma.
\end{abstract}

\section{Introduction}

Regulatory mechanisms of ovulatory follicular rupture have been a subject of investigation for more than a century (see the comprehensive overview by Espey and Lipner, 1994); notwithstanding, essential ovarian pathways remain uncertain. A role for proteolytic enzymes in the degradation of connective tissue elements of the ovarian wall was apparent from the outset. Numerous studies have since implicated the plasminogen activator/plasmin and collagenolytic systems in the mechanism of ovulation. That programmed cell death (apoptosis) occurs within the developmental site of ovulation is a new discovery. A prospective mediator of ovulatory ovarian apoptosis is tumour necrosis factor $\alpha$ (TNF $\alpha$ ). The objective of this overview is to summarize recent evidence based largely on work in sheep denoting an interaction between plasmin and TNF $\alpha$ in ovulation.

\section{Experimental Paradigm}

Mature western-range ewes were penned daily with vasectomized rams and observed for oestrous behaviour. The first day of oestrus was considered day 0 of the oestrous cycle. Animals were treated with prostaglandin $\mathrm{F}_{2 \alpha}\left(\mathrm{PGF}_{2 \alpha}\right)$ on day 14 to synchronize luteal regression. A synthetic agonist of GnRH was administered $36 \mathrm{~h}$ after $\mathrm{PGF}_{2 \pi}$ to generate a preovulatory surge of gonadotrophins (natural surges commence at approximately $40 \mathrm{~h}$ ). The follicle of greatest visible diameter within the pair of ovaries will ovulate approximately $24 \mathrm{~h}$ after injection of GnRH and form a normal corpus luteum (Roberts et al., 1985). A translucent ovulatory stigma develops within $2 \mathrm{~h}$ of follicular rupture (Murdoch, 1985).

\section{Plasmin Upregulation at the Ovarian Surface-Preovulatory Follicular Interface}

Plasmin (fibrinolysin) is a pleiotrophic serine protease that is derived from the zymogen plasminogen by enzymatic activation. Two forms of plasminogen activator have been characterized in vertebrates - urokinase ( $\mathrm{UPA}$ ) and tissue (tPA) types. Catalytic uPA can exist either as high (about $50 \mathrm{kDa}$ ) or low (about $30 \mathrm{kDa}$ ) molecular mass variants. The major tPA has a molecular mass of approximately $70 \mathrm{kDa}$ and has a strong affinity (unlike uPA) for fibrin (Danø et al., 1985). Secretion of plasminogen activators by thecal and granulosal cells of gonadotrophin-stimulated follicles has been established; both uPA and tPA apparently contribute to preovulatory ovarian plasmin biosynthesis in rodents (Tsafriri and Reich, 1991; Hägglund et al., 1996). 
An auxiliary source of plasminogen activator is the ovarian surface epithelium. Accordingly, an increase in plasmin within the apical hemisphere of preovulatory ovine follicles (plus conjoined tunica albuginea) at $12 \mathrm{~h}$ after $\mathrm{GnRH}$ administration was attributed to secretion of low molecular mass uPA by ovarian surface epithelial cells ( $t P A$ was undetectable). When ovarian surface epithelium was surgically removed at $8 \mathrm{~h}$ after GnRH treatment, the follicular rise in uPA was negated and ovarian rupture was inhibited. Furthermore, ovulation was suppressed by intrafollicular injections of uPA (but not tPA) antibodies at $8 \mathrm{~h}$ (Colgin and Murdoch, 1997) or $\alpha_{2}$-antiplasmin at $16 \mathrm{~h}$ (Murdoch, 1998a) after GnRH. Plasminogen activators were also increased preferentially within the apices of preovulatory porcine (Smokovitis et al., 1988) and rat (Peng et al., 1993) follicles and intrabursal administration of inhibitors of the plasminogen activator/plasmin system decreased ovulation rates in rats (Tsafriri and Reich, 1991). Interestingly, in certain species (for example horse and armadillo) ovulation is restricted to a discrete ovarian depression (fossa) covered by prototypical (coelomic mesothelial-derived) surface epithelium (Mossman and Duke, 1973).

Local controlling mechanisms of uPA secretion by sheep ovarian surface epithelial cells are equivocal. Receptors for gonadotrophins have been detected on ovarian surface cells (Godwin et al., 1993). In fact, isolated sheep ovarian surface epithelial cells secrete uPA in response to LH (D. C. Colgin and W. J. Murdoch, unpublished observation). It is conceivable that cells in close proximity to the preovulatory follicle are readily exposed to surge gonadotrophin concentrations because of a marked acute increase (4-12 h after $\mathrm{GnRH}$ ) in permeability of the thecal vascular wreath (Halterman and Murdoch, 1986; Cavender and Murdoch, 1988).

\section{Collagenolytic Activation}

It appears that plasmin activates latent collagenases (Danø et al., 1985) which degrade the matrices of connective tissue of the follicular theca and tunica albuginea, thereby weakening the ovarian wall (Tsafriri and Reich, 1991). The general consensus of functional studies on plasminogen activators is that uPA regulates tissue degradation, while tPA is involved in thrombolysis (Danø et al., 1985; Hart and Rehemtulla, 1988).

In preovulatory ovine follicles there is a close correlation between apical plasmin accumulation (Colgin and Murdoch, 1997) and the onset of collagen dissolution (Murdoch and McCormick, 1992). Explants of follicular wall released hydroxyproline-containing peptides (degraded collagen) upon exposure to plasmin and injection of $\alpha_{2}$-antiplasmin intó preovulatory follicles inhíbited collagenase bioactivity of tissue extracts (Murdoch, 1998a). Morphological observations indicate that preovulatory connective tissue breakdown begins at the ovarian surface and advances inward toward the follicular wall (Bjersing and Cajander, 1975; Talbot et al., 1987).

\section{Induction of Cell Death by TNF $\alpha$}

Marked alterations in organ morphology are often associated with a programmed process of active physiological cell death or apoptosis. Early-stage apoptosis is distinguished by calcium influx, endonuclease activation, internucleosomal DNA fragmentation, and nuclear pyknosis. Apoptotic cells shrink and lose contact with their neighbours and supporting basement membranes. Residual bodies typically are resorbed by adjacent epithelial cells or resident macrophages. Cells undergoing apoptosis may disappear completely within a few hours (Ellis et al., 1991; Schwartzman and Cidlowski, 1993).

Direct in situ fluorescence detection of digoxigenin end-labelled genomic DNA was used as a marker of nuclear apoptosis within preovulatory ovine follicles and surrounding ovarian tissues. As the time of ovulation approached (16-24 h after $\mathrm{GnRH})$, there was a progressive increase in apoptotic cells within the ovarian surface epithelium, tunica albuginea and apical follicular wall. At the avascular site of impending rupture, follicles were almost devoid of ovarian surface and granulosal epithelia (dispersion of granulosa within the basal region of preovulatory follicles was 
not associated with apoptosis). Sloughing of ovarian surface epithelial cells occurred first, followed by cell losses within the tunica albuginea and follicular wall (Murdoch, 1994, 1995a,b). Thus, discrete physicochemical interactions between preovulatory follicles and the ovarian surface are evidently a prelude to programmed cell deletion and ovulation.

Our initial inclination was that prostaglandins were somehow involved in the biomechanics of apoptotic cell death within the formative ovulation papilla of sheep follicles. That prostaglandins are produced by follicular and ovarian surface cells during the preovulatory period (Murdoch et al., 1991, 1993) and (at high doses in vitro) can provoke ovarian apoptotic cell death was established (Ackerman and Murdoch, 1993). It was therefore predicted that indomethacin, an inhibitor of prostaglandin biosynthesis and ovulation (Murdoch et al., 1993), would protect apical ovarian cells from programmed death. The anti-ovulatory potencies of two systemic doses of indomethacin (200 or $800 \mathrm{mg}$ given $8 \mathrm{~h}$ after $\mathrm{GnRH}$ ) were tested. Ovulation did not occur after administration of $800 \mathrm{mg}$ indomethacin but was not inhibited by $200 \mathrm{mg}$ indomethacin. Both doses of the drug suppressed follicular prostaglandin production below pre-gonadotrophin values. Fragmentation of DNA was averted among ovarian surface epithelial and granulosal cells recovered from the apical dome of follicles ( $16 \mathrm{~h}$ after $\mathrm{GnRH}$ ) of ewes given $800 \mathrm{mg}$ indomethacin, whereas apoptosis ensued after $200 \mathrm{mg}$ indomethacin. Intracellular calcium accretion detected by fluorescence of fura- 2 was increased in ovarian cells of animals destined to ovulate ( $200 \mathrm{mg}$ indomethacin) in comparison to (safeguarded) cells of anovulatory ewes ( $800 \mathrm{mg}$ indomethacin) (Murdoch, 1996a). These observations provided circumstantial evidence that apical ovarian cell degeneration by calcium-mediated apoptosis is a determinant of follicular instability and rupture, but that these events are unrelated to the gonadotrophin-induced increase in prostanoid production characteristic of preovulatory follicles.

We then investigated the close relationship between plasmin upregulation and TNF $\alpha$ secretion within the apex of preovulatory follicles (Murdoch et al., 1997). Tumour necrosis factor $\alpha$ is expressed as a $26 \mathrm{kDa}$ integral transmembrane precursor molecule which upon proteolytic cleavage yields a $17 \mathrm{kDa}$ extracellular domain subunit. Mature (cytotoxic) TNF $\alpha$ is a noncovalent trimer. Common cell types known to produce TNF $\alpha$ are leucocytes, smooth muscle, fibroblasts, and endothelium. Plasma membrane receptors for TNF $\alpha$ (R55, R75) are present on almost all nucleated cells (Vilcek and Lee, 1991; Vandenabeele et al., 1995), including cells of the mammalian ovary (Terranova, 1997). It is now apparent that, in addition to its ability to induce lytic cell death (haemorrhagic necrosis), TNF $\alpha$ can transduce an apoptotic signal that results in programmed cell death (Larrick and Wright, 1990; Haanen and Vermes, 1995; Steller, 1995).

Tumour necrosis factor $\alpha$ was localized by indirect immunofluorescence microscopy to thecal endothelial cells of preovulatory ovine follicles (Murdoch et al, 1997). Immunostaining of endothelial cells within the follicular apex declined abruptly with the approach of ovulation (cells within the counterpart basal wall were unaffected); it appeared that TNF $\alpha$ had been released into the progenitor site of ovulation. Intrafollicular injection ( $10 \mathrm{~h}$ after $\mathrm{GnRH}$ ) of TNF $\alpha$ antiserum circumvented ovarian DNA fragmentation and blocked ovulation in ewes. Moreover, TNF $\alpha$ (at physiologically relevant concentrations) induced ovarian cell apoptosis in vitro (Murdoch et al., 1997) and ovulation rates were enhanced by addition of TNF $\alpha$ to perfusates of rat ovaries (Brännström et al., 1995).

The biomechanics of TNF $\alpha$ expression and release from resident ovarian cells have not been elucidated. It is unlikely that a stimulatory effect of gonadotrophin on TNF $\alpha$. secretion is direct, but rather is mediated by other agents in response to hormonal stimulation (Terranova, 1997). Tumour necrosis factor $\alpha$ is a candidate substrate for serine protease (perhaps plasmin) attack (Scuderi, 1989; Perona and Craik, 1995). Intrafollicular $\alpha_{2}$-antiplasmin averted preovulatory apical TNF $\alpha$-mediated cellular DNA fragmentation and plasmin-stimulated bioactive TNF $\alpha$ release from follicular explants (Murdoch, 1998a). In recent studies (W. J. Murdoch and E. A. Van Kirk, unpublished), cleavage by plasmin of TNF $\alpha$ exodomain from its membrane anchor on thecal endothelial cells appeared to be responsible for programming apoptotic death among ovarian cells within a limited diffusion radius. At high tissue concentrations, TNF $\alpha$ also initiates microvascular coagulation associated with necrotic cell death (Larrick and Wright, 1990) and inflammatory tissue damage symptomatic of the ovulatory process (Espey, 1980). Vascular lesions typical of haemorrhagic necrosis are observed 


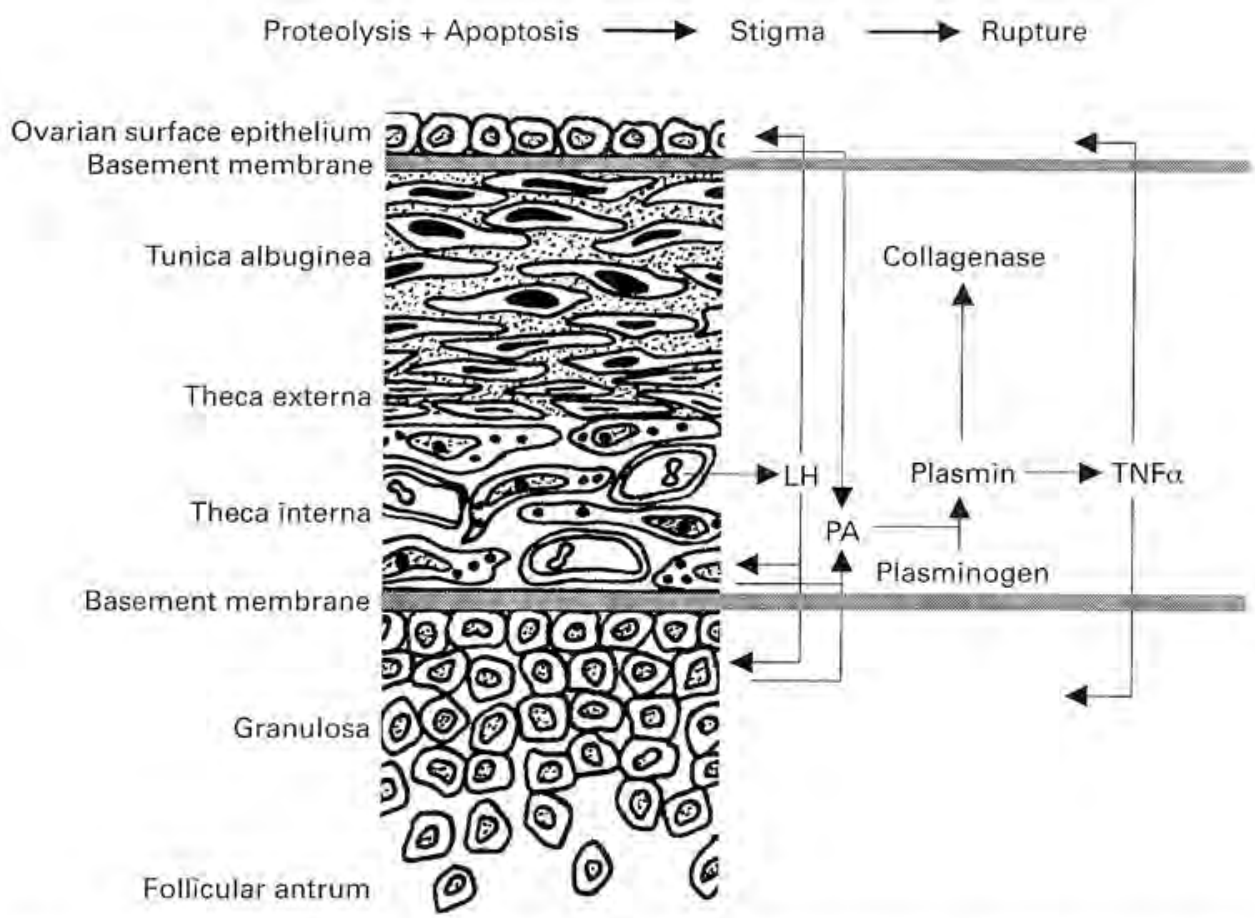

Fig. 1. A working model of proposed interactions of $\mathrm{LH}$, ovarian cell types, plasminogen activator (PA)/plasmin, and tumour necrosis factor $\alpha$ (TNF $\alpha$ ) in the breakdown of the apical follicular wall during ovulation in sheep: vascular transudate containing gonadotrophin is delivered to receptorbearing cells (i.e. granulosa, theca interna, surface epithelium) of the ovarian wall, thereby stimulating secretion of plasminogen activator; interstitial plasminogen is converted to plasmin, which activates latent collagenases and cleaves TNF $\alpha$ from its endothelial mooring; collagenases disrupt the fibril network of the theca and tunica albuginea and promote disintegration of the basement membranes supporting the ovarian and granulosal epithelia; TNF $\alpha$ induces apoptosis; collagenolysis and cellular effacement dictate stigma development and follicular rupture.

within the immediate area surrounding the stigma of the preovulatory ovine follicle (Cavender and Murdoch, 1988; Murdoch and Cavender, 1989). A lack of blood flow (ischaemia) into the ovulation papilla, leading to oxygen deprivation and toxic metabolite accumulation, would predictably potentiate cell death. Experiments are underway to determine whether the anti-ovulatory effect of indomethacin is related to a (prostaglandin-independent) abrogation of TNF $\alpha$ action.

Finally, mechanical forces may combine with connective tissue degradation and cell elimination to assure tissue thinning and follicular rupture. Retraction of the basal theca due to contractility (Martin and Talbot, 1981) would theoretically cause the opposing wall to recede from the ovarian surface.

\section{Ovulation and Wound Repair}

Ovulation creates a wound along the ovarian surface that is repaired during the ensuing luteal phase. Inauspiciously, some cells at the margins of ruptured follicles that endure the ovulatory (TNF $\alpha$ ) insult contain fragmented DNA (Ackerman and Murdoch, 1993; Murdoch, 1994, 1995a, 1998b). Damage to DNA that is uncorrected could be problematic if propagated; indeed, most ovarian cancers apparently originate by malignant clonal transformation of a surface epithelial cell 
traumatized at ovulation (Hamilton, 1992; Godwin et al., 1993; Murdoch, 1996b): Sublethal damage to DNA that is inflicted upon ovarian surface cells can evidently be reconciled by repair enzymes induced on a localized basis by progesterone of luteal origin (Murdoch, 1998b).

\section{Conclusion}

On the basis of the cited investigations, plasmin has an intermediary role in the proteolytic and cell death mechanisms of follicular stigma formation and ovulatory ovarian rupture in sheep. A role for plasmin in the stimulation of collagenases is well known. However, a pivotal function of plasmin in the bioactivation of TNF $\alpha$ is novel. A synopsis of putative interactions of gonadotrophin, apical ovarian tissues, plasminogen activator/plasmin, and TNF $\alpha$ in the ovulatory process of the sheep is depicted in Fig. 1.

\section{References}

Ackerman RC and Murdoch WJ (1993) Prostaglandin-induced apoptosis of ovarian surface epithelial cells Prostaglnudins $45473-483$

Bjersing L and Cajander S (1975) Ovulation and the role of the ovarian surface epithelium Experientia 31 605-608

Brännström M, Bonello N, Wang LJ and Norman RJ (1995) Effects of tumour necrosis factor $\alpha$ on ovulation in the rat ovary Reproduction Fertility and Developutent 7 67-73

Cavender JL and Murdoch WJ (1988) Morphological studies of the microcirculatory system of periovulatory ovine follicles Biology of Reproduction $39989-997$

Colgin DC and Murdoch WJ (1997) Evidence for a role of the ovarian surface epithelium in the ovulatory mechanism of the sheep: secretion of urokinase-type plasminogen activator Animal Reproduction Science 47 197-204

Dane K, Andreasen PA, Grondahl-Hansen J, Kristensen P, Nielsen LS and Skriver L (1985) Plasminogen activators, tissue degradation, and cancer Advances in Comcer Research 44 139-266

Ellis RE, Yuan J and Horvitz HR (1991) Mechanisms and functions of cell death Annual Review of Cell Biology 7 663-698

Espey LL (1980) Ovulation as an inflammatory reaction - a hypothesis Biology of Reproduction 22 73-106

Espey LL and Lipner H (1994) Ovulation. In The Physiology of Reproduction pp 725-780 Eds E Knobil and JD Neill. Raven Press, New York

Godwin AK, Testa JR and Hamilton TC (1993) The biology of ovarian cancer development Cancer 71 530-536

Haanen C and Vermes 1 (1995) Apoptosis and inflammation Mediators of Inflammation 45-15

Hägglund A-C, Ny A, Liu K and Ny T (1996) Coordinated and cell-specific induction of both physiological plasminogen activators creates functionally redundant mechanisms for plasmin formation during ovulation Endocrinology 137 5671-5677

Halterman SD and Murdoch WJ (1986) Ovarian function in ewes treated with antihistamines Endocrinology 119 2417-2421

Hamilton TC (1992) Ovarian cancer, biology Current Problems in Cancer 16 5-57

Hart DA and Rehemtulla A (1988) Plasminogen activators and their inhibitors: regulators of extracellular proteolysis and cell function Comparative Biochemistry and Physiology 90B 691-708
Larrick JW and Wright SC (1990) Cytotoxic mechanism of tumor necrosis factor- $\alpha$ FASEB Joumal 4.3215-3223

Martin GG and Talbot P (1981) The role of follicular smooth muscle cells in hamster ovulation Journal of Experimental Zoology 216 469-482

Mossman HW and Duke KL (1973) Comparative Morphology of the Mammalian Ovary University of Wisconsin Press, Madison

Murdoch WJ (1985) Follicular determinants of ovulation in the ewe Domestic Animal Endocrinology 2 105-121

Murdoch WJ (1994) Ovarian surface epithelium during ovulatory and anovulatory ovine estrous cycles Anatomical Record 240 322-326

Murdoch WJ (1995a) Programmed cell death in preovulatory ovine follicles Biology of Reproduction 53 8-12

Murdoch WJ (1995b) Endothelial cell death in preovulatory ovine follicles: possible implication in the biomechanics of rupture Joumal of Reproduction and Fertility 105 161-164

Murdoch WJ (1996a) Differential effects of indomethacin on the sheep ovary: prostaglandin biosynthesis, intracellular calcium, apoptosis, and ovulation Prostaglandins 52 497-506

Murdoch WJ (1996b) Ovarian surface epithelium, ovulation, and carcinogenesis Biological Reviews 71 529-543

Murdoch WJ (1998a) Regulation of collagenolysis and cell death by plasmin within the formative stigma of preovulatory ovine follicles Journal of Reproduction and Fertility 113 331-336

Murdoch WJ (1998b) Perturbation of sheep ovarian surface epithelial cells by ovulation: evidence for roles of progesterone and poly(ADP-ribose) polymerase in the restoration of DNA integrity Journal of Endocrinology 156 503-508

Murdoch WJ and Cavender JI. (1989) Effect of indomethacin on the vascular architecture of preovulatory ovine follicles: possible implication in the luteinized unruptured follicle syndrome Fertility and Sterility 51 153-155

Murdoch WJ and McCormick RJ (1992) Enhanced degradation of collagen within apical vs. basal wall of ovulatory ovine follicle American Journal of Physiology 263 E221-E225

Murdoch WJ, Slaughter RG and Ji TH (1991) In situ hybridization analysis of ovarian prostaglandin endoperoxide synthase mRNA throughout the periovulatory period of the ewe Domestic Animal Endocrinology 8457-459

Murdoch WJ, Hansen TR and McPherson LA (1993) Role of eicosanoids in vertebrate ovulation Prostnglandins 46 85-115 
Murdoch WJ, Colgin DC and Ellis JA (1997) Role of tumor necrosis factor- $\alpha$ in the ovulatory mechanism of ewes Journal of Animal Science 75 1601-1605

Peng X-R, Hsueh AJW and Ny T (1993) Transient and cellspecific expression of tissue-type plasminogen activator and plasminogen-activator-inhibitor type 1 results in controlled and directed proteolysis during gonadotropininduced ovulation European Fourral of Biochemistry 214 147-156

Perona JJ and Craik CS (1995) Structural specificity in the serine proteases Protein Science 4 337-360

Roberts AJ, Dunn TG and Murdoch WJ (1985) Induction of avulation in proestrous ewes: identification of the ovilatory follicle and functional status of the corpus luteum Domestic Antmal Endocrinology 2 207-210

Schwartzman RA and Cidlowski JA (1993) Apoptosis: the biochemistry and molecular biology of programmed cell death Endocrine Reviews 14 133-151

Scuderi P (1989) Suppression of human leukocyte tumor necrosis factor secretion by the serine protease inhibitor $p$ toluenesulfonyl- $L$-arginine methyl ester jourrial of Immunology 143 168-173.
Smokovitis A, Kokolis N and Alexaki-Tzivanidou E (1988) The plasminogen activator activity is markedly increased mainly at the area of the rupture of the follicular wall at the time of ovulation Animal Reproduction Science $\mathbf{1 6}$ 285-294

Steller H (1995) Mechanisms and genes of cellular suicide Science 267 1445-1449

Talbot P, Martin GG and Ashby H (1987) Formation of the rupture site in preovulatory hamster and mouse follicles: loss of surface epithelium Gamete Research 17 287-302

Terranova PF (1997) Potential roles of tumor necrosis factor- $\alpha$ in follicular development, ovulation, and the life span of the corpus luteum Domestic Animal Endocrinology 14 1-15

Tsafriri A and Reich R (1991) Plasminogen activators in the preovulatory follicle: role in ovulation. In Plasminogen Activators: From Cloning To Therapy pp 81-93 Eds R Abbate, T Barni and A Tsafriri. Raven Press, New York

Vandenabeele P, Declercq W, Beyaert R and Fiers W (1995) Two tumour necrosis factor receptors: structure and function Trends in Cell Biology 5 392-399

Vilcek $I$ and Lee TH (1991) Tumor necrosis factor Jouthal of Biological Chemistry 266 7313-7316 